\title{
Partial Oxidation of Methane over $\mathrm{CeO}_{2}$ Catalyst
}

\author{
Hỵun-Seog Roh, Ki-Won Jun," Seung-Chan Baek, and Sang-Eon Park" \\ Chemical Technolog: Division, Korea Research Institute of Chemical Technolog:, \\ P.O. Box 107, Yuseong, Daejeon 305-600, Korea
}

Received November 5, 2001

\begin{abstract}
Partial oxidation of methane has been conducted over $\mathrm{CeO}_{2}$ and it has been found that $\mathrm{CeO}_{2}$ has an extraordinary catalytic activity in the reaction. Its activity was strongly dependent on the $\mathrm{CH}_{4} \mathrm{O}_{2}$ ratio. Total combustion was dominant with stoichiometric feed ratio $\left(\mathrm{CH}_{4} \mathrm{O}_{2}=2.0\right)$ but partial oxidation was favorable with oxygen deficient feed condition. Meanwhile, oscillatory partial oxidation was achieved between the $\mathrm{CH}_{4}$ $\mathrm{O}_{2}$ ratio of 3.8 and 4.3 and the period depended upon the feed composition. The proposed reaction mechanism is that oxygen vacancies in reduced ceria are supplied with oxygen molecules from the reactant, and then activate adsorbed oxygen, followed by releasing activated oxygen species reacting with methane to produce $\mathrm{H}_{2}$ and $\mathrm{CO}$.
\end{abstract}

Keywords : $\mathrm{CeO}_{2}$, Methane, Partial oxidation.

\section{Introduction}

Catalytic partial oxidation of methane (POM) is of great practical importance in producing hydrogen or synthesis gas by using natural gas. ${ }^{1-3}$ POM offers the alternatively greatest potential for fast, efficient and economical conversion of methane to hydrogen or synthesis gas, due to the mild exothermicity, high conversion, high selectivity, suitable $\mathrm{H}_{2} / \mathrm{CO}$ ratio for the Fischer-Tropsch and methanol synthesis, and the very short residence time. Therefore, POM has been studied over numerous supported metal catalysts such as $\mathrm{Ni}$ based catalysts and supported noble metal catalysts. ${ }^{1}$

Rare earth oxides have been widely investigated in catalysis as structural and electronic promoters to improve the activity, selectivity and thermal stability of catalysts. ${ }^{4} \mathrm{CeO}_{2}$ has been considered as the most important rare earth element in catalysis. It plays an important role in three-way catalysis (TWC) and fluid catalytic cracking (FCC). ${ }^{+}$Specifically, $\mathrm{CeO}_{2}$ has potential uses for the removal of soot from diesel engine exhaust, oxidation), ${ }^{6}$ as an additive for combustion catalysts, ${ }^{7}$ in fuel cell systems. ${ }^{8}$ Therefore, much effort has been dedicated to studying the role of ceria. As a result, it is known that the high oxygen storage capacity ( $\mathrm{OSC}$ ) of $\mathrm{CeO}_{2}$ improves catalytic performance by storing oxygen during oxidation and releasing it during reduction. ${ }^{9.10^{\circ}}$ Otsuka et $\mathrm{al}^{11}$ found that $\mathrm{CeO}_{2}$ is an unusual oxidant for oxidation of $\mathrm{CH}_{4}$ into synthesis gas with a $\mathrm{H}_{2} / \mathrm{CO}$ ratio of 2 without producing $\mathrm{H}_{2} \mathrm{O}$ and $\mathrm{CO}_{2}$ at $873-1073 \mathrm{~K}$. However, the POM reaction was executed by passing a mixture of $\mathrm{CH}_{4}$ and $\mathrm{Ar}(1: 1)$ after

"Corresponding author. Fax: +82-42-860-7388; e-mail: kwjun( krict.re.kr
$\mathrm{CeO}_{2}$ was pretreated in a $1: 1$ mixture of $\mathrm{O}_{2}$ and $\mathrm{Ar}$ for $1 \mathrm{~h}$ at $973 \mathrm{~K}$. Strictly speaking, $\mathrm{CeO}_{2}$ was not employed as a catalyst for POM but an oxidant for $\mathrm{CH}_{4}$ oxidation.

Recently, we have reported that $\mathrm{Ni} / \mathrm{Ce}-\mathrm{ZrO}_{2}$ exhibited high activity as well as high stability in $\mathrm{POM}^{12,13}$ steam reforming of methane (SRM), ${ }^{1+15}$ and oxy-SRM (OSRM: simultaneous POM and SRM). ${ }^{1 \leqslant}$ In the case of $\mathrm{Ni}^{\circ} \mathrm{CeO}_{2}$, it showed a very low activity in $\mathrm{SRM}_{3}{ }^{11.12}$ however, it exhibited fairly good activity in $\mathrm{POM}^{12}$ and remarkably high activity as well as stability in OSRM. ${ }^{15}$ Thus, we have aimed to investigate the role of $\mathrm{CeO}_{2}$ in $\mathrm{POM}$ and OSRM, resulting in finding out very interesting results. We have reported as a communication ${ }^{16}$ that $\mathrm{CeO}_{2}$ shows extraordinary catalytic behavior strongly depending on the feed composition of $\mathrm{CH}_{4}$ and $\mathrm{O}_{2}$ and could catalyze POM giving a $\mathrm{H}_{2} / \mathrm{CO}$ ratio of 2 with oxygen deficient feed. We report here the detailed POM results and explain the strange catalytic behavior.

\section{Experimental Section}

The $\mathrm{CeO}_{2}$ sample employed was a reagent-grade (purity $>99.9 \%$ ) having a BET surface area of $19 \mathrm{~m}^{2} / \mathrm{g}$. Activity tests were carried out at $1023 \mathrm{~K}$ under atmospheric pressure in a fixed-bed quartz reactor. ${ }^{12-16}$ Each catalyst $(50 \mathrm{mg}$ ) was loaded into the quartz reactor with an inner diameter of 4 $\mathrm{mm}$. The reaction temperature was measured and controlled by a thermocouple directly inserted into the top layer of the catalyst bed. Prior to each reaction test, the catalyst was reduced in $5 \% \mathrm{H}_{2} / \mathrm{N}_{2}$ at $973 \mathrm{~K}$ for $3 \mathrm{~h}$. Effluent gases from the reactor were analyzed by an on-line gas chromatograph (Chrompack CP9001) equipped with a capillary column (CarboPLOT P7) and a thermal conductivity detector.

Pulse experiments using $\mathrm{CH}_{4}, \mathrm{O}_{2}$ and $\mathrm{CH}_{4} / \mathrm{O}_{2}$ mixed gas 
$\left(\mathrm{CH}_{4} / \mathrm{O}_{2}=2\right)$ were performed in the quartz micro-reactor with an inner diameter of $4 \mathrm{~mm}$. Before the reaction, $15 \mathrm{mg}$ of each catalyst was loaded in the reactor and reduced in sitt in $5 \% \mathrm{H}_{2} / \mathrm{N}_{2}$ at $700^{\circ} \mathrm{C}$ for $3 \mathrm{~h}$. Detailed procedures for pulse experiments were described previously. ${ }^{17,18}$ The conversion and selectivity were calculated on the basis of $100 \%$ carbon and oxygen balances. The $\mathrm{CO}$ and $\mathrm{CO}_{2}$ selectivities were defined in elsewhere. ${ }^{17}$

\section{Results and Discussion}

Continuous reaction. Figure 1 shows catalytic performance of $\mathrm{CeO}_{2}$ at the stoichiometric feed ratio $\left(\mathrm{CH}_{4} \mathrm{O}_{2}=\right.$ 2.0). $\mathrm{CH}_{4}$ and $\mathrm{O}_{2}$ conversions were $26 \%$ and $87 \%$, respectively. However, both $\mathrm{H}_{2}$ and $\mathrm{CO}$ selectivities were less than $5 \%$, indicating that the resultant products were $\mathrm{H}_{2} \mathrm{O}$ and $\mathrm{CO}_{2}$ resulting from total combustion. Figure 2 illustrates catalytic performance of $\mathrm{CeO}_{2}$ at the condition of $\mathrm{CH}_{4} / \mathrm{O}_{2}=3.0$. Initially $\mathrm{CH}_{4}$ conversion was $7 \%$ and $\mathrm{O}_{2}$ conversion was almost zero with a $\mathrm{H}_{2} / \mathrm{CO}$ ratio of 2.0 . This is mainly due to the fact that mobile oxygen species on $\mathrm{CeO}_{2}$ were consumed to react with $\mathrm{CH}_{4}$. With increasing time on stream, both $\mathrm{CH}_{4}$

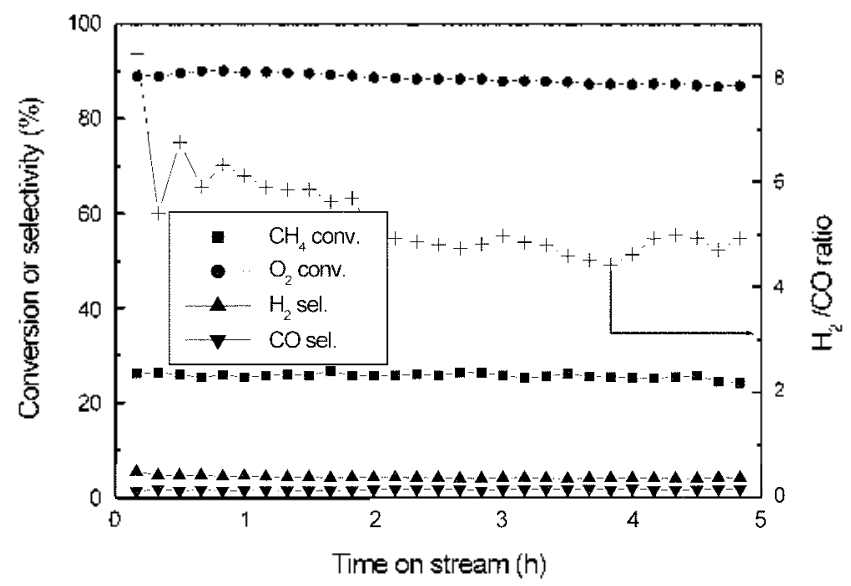

Figure 1. $\mathrm{CH}_{4}$ oxidation over $\mathrm{CeO}_{2}$ with a $\mathrm{CH}_{4} / \mathrm{O}_{2}$ ratio of 2.0 $\left(\mathrm{CH}_{\downarrow}=30 \mathrm{~mL} / \mathrm{min}, 50 \mathrm{mg}\right.$ catalyst, $\left.\mathrm{T}=1023 \mathrm{~K}, \mathrm{P}=\mathrm{l} \mathrm{atm}\right)$.

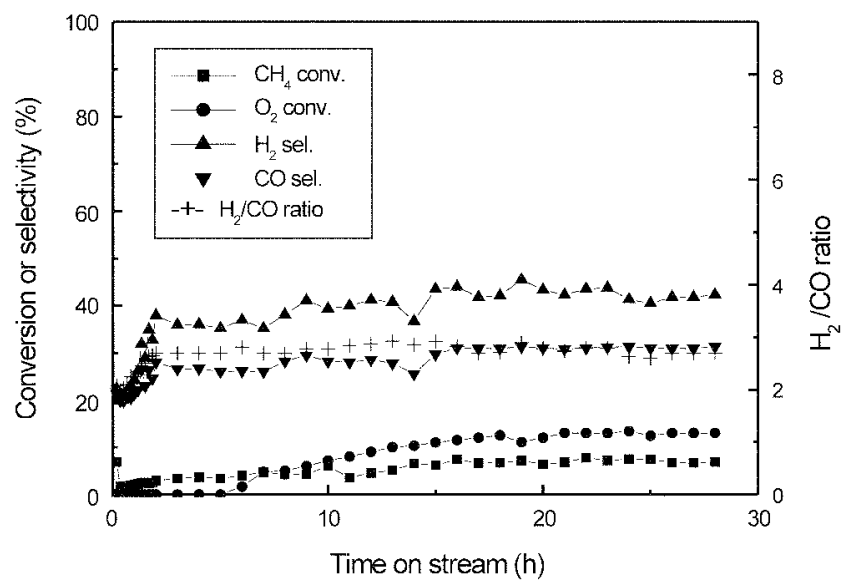

Figure 2. $\mathrm{CH}_{4}$ oxidation over $\mathrm{CeO}_{2}$ with a $\mathrm{CH}_{4} \mathrm{O}_{2}$ ratio of 3.0 $\left(\mathrm{CH}_{4}=30 \mathrm{~mL} / \mathrm{min}, 50 \mathrm{mg}\right.$ catalyst, $\left.\mathrm{T}=1023 \mathrm{~K}, \mathrm{P}=1 \mathrm{~atm}\right)$.

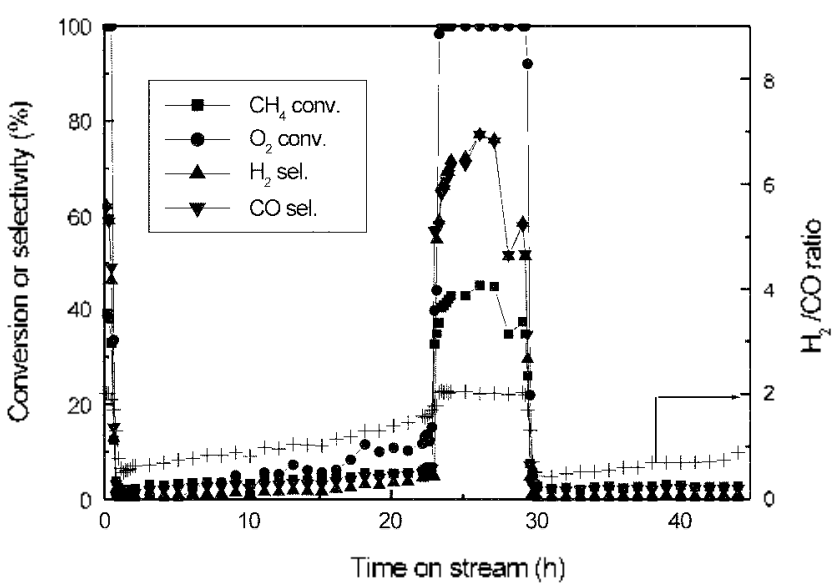

Figure 3. $\mathrm{CH}_{4}$ oxidation over $\mathrm{CeO}_{2}$ with a $\mathrm{CH}_{4} / \mathrm{O}_{2}$ ratio of 3.8 (CH $\mathrm{CH}_{4}=30 \mathrm{~mL} / \mathrm{min}, 50 \mathrm{mg}$ catalyst, $\mathrm{T}=1023 \mathrm{~K}, \mathrm{P}=1 \mathrm{~atm}$ ).

and $\mathrm{O}_{2}$ conversions reached steady state with their values of $7 \%$ and $13 \%$, respectively. These conversions were lower than those at $\mathrm{CH}_{4} / \mathrm{O}_{2}=2.0$, however, the selectivities to $\mathrm{H}_{2}$ and $\mathrm{CO}$ were $46 \%$ and $31 \%$, suggesting that $\mathrm{POM}$ was considerable. These results reveal that POM is favorable over $\mathrm{CeO}_{2}$ at oxygen deficient environment. Meanwhile, the $\mathrm{H}_{2} / \mathrm{CO}$ ratio reached about 2.7 at steady state. This is possibly due to the water gas shift (WGS) reaction or $\mathrm{CO}$ combustion reaction. Actually, $\mathrm{CeO}_{2}$ has been reported to enhance the removal of $\mathrm{CO}$ and to promote WGS. ${ }^{19,20}$ The results at a $\mathrm{CH}_{4} \mathrm{O}_{2}$ ratio of 3.8 are presented in Figure 3 . Surprisingly, maximum $\mathrm{CH}_{4}$ and $\mathrm{O}_{2}$ conversions in this condition were $45 \%$ and $100 \%$, respectively. Both $\mathrm{H}_{2}$ and $\mathrm{CO}$ selectivities were $77 \%$ giving a $\mathrm{H}_{2} / \mathrm{CO}$ ratio of 2.0 , indicating that POM was dominant in this condition. Besides, catalytic behavior with time on steam was extraordinary. At the beginning, $\mathrm{CeO}_{2}$ exhibited high $\mathrm{CH}_{4}$ conversion $(39 \%)$, $\mathrm{H}_{2}$ selectivity $(62 \%)$ and $\mathrm{CO}$ selectivity $(62 \%)$ giving a $\mathrm{H}_{2} /$ $\mathrm{CO}$ ratio of 2.0 . The activities decreased sharply and became almost zero after $1 \mathrm{~h}$. After that, however, $\mathrm{CH}_{4}$ conversion increased gradually with time on stream, and it dramatically reached about $40 \%$ after $23 \mathrm{~h}$ and maintained between 23 and $30 \mathrm{~h}$. After $30 \mathrm{~h}$, the phenomena were repeated. The trends of both $\mathrm{H}_{2}$ and $\mathrm{CO}$ selectivities were similar to that of $\mathrm{CH}_{4}$ conversion. Interestingly, the $\mathrm{H}_{2} / \mathrm{CO}$ ratio was closely 2.0 initially, decreased to 0.5 after $1 \mathrm{~h}$, and steadily increased to 2.0 after $23 \mathrm{~h}$. The increasing rate of the $\mathrm{H}_{2} / \mathrm{CO}$ ratio was rather faster than that of $\mathrm{CH}_{4}$ conversion. These results can be explained as follows. At the beginning, reduced ceria $\left(\mathrm{Ce}_{1.2 y}{ }^{++} \mathrm{Ce}_{2 y y}{ }^{3-} \mathrm{O}_{2-y}\right)$ store oxygen molecules from the reactant and release them as active oxygen species reacting with methane to produce synthesis gas at oxygen deficient condition. During the reaction, reduced ceria are fast oxidized by $\mathrm{O}_{2}$ feed $\left(\mathrm{Ce}_{1.2 y}{ }^{4+} \mathrm{Ce}_{2 y}{ }^{3+} \mathrm{O}_{2-y}+0.5 \mathrm{yO}_{2} \rightarrow \mathrm{CeO}_{2}\right)$, showing almost negligible activity in POM. And then, oxidized ceria are gradually reduced by hydrogen produced from $\mathrm{POM}$ or methane decomposition $\left(\mathrm{CeO}_{2}+\mathrm{yH}_{2} \rightarrow \mathrm{Ce}_{1 \cdot 2 y}{ }^{4-} \mathrm{Ce}_{2 y}{ }^{{ }^{2}-} \mathrm{O}_{2 \cdot y}+\right.$ $\left.\mathrm{yH}_{2} \mathrm{O}\right)$. The trend of the $\mathrm{H}_{2} / \mathrm{CO}$ ratio supports this mechanism because the ratio was initially 2.0 and sharply 


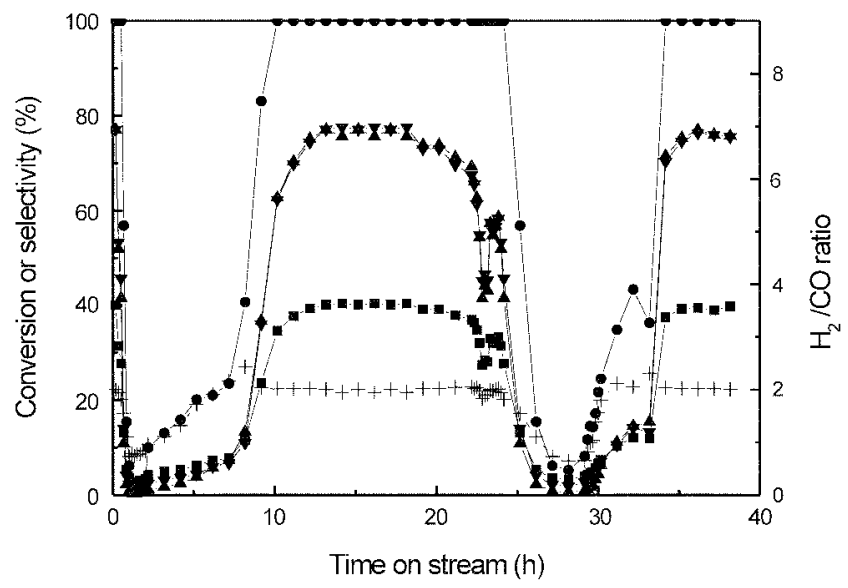

Figure 4. $\mathrm{CH}_{4}$ oxidation over $\mathrm{CeO}_{2}$ with a $\mathrm{CH}_{4} / \mathrm{O}_{2}$ ratio of 4.3 $\left(\mathrm{CH}_{\downarrow}=30 \mathrm{~mL} / \mathrm{mun}, 50 \mathrm{mg}\right.$ catalyst, $\left.\mathrm{T}=1023 \mathrm{~K}, \mathrm{P}=1 \mathrm{~atm}\right)$.

decreased to 0.5 , and then gradually increased to 2.0 . In other words, the hydrogen produced from $\mathrm{POM}$ or $\mathrm{CH}_{4}$ decomposition was gradually consumed to reduce $\mathrm{CeO}_{2}$ resulting in low $\mathrm{H}_{2} / \mathrm{CO}$ ratio. In the case of $\mathrm{CH}_{4} \mathrm{O}_{2}=4.3$, maximum $\mathrm{CH}_{4}$ and $\mathrm{O}_{2}$ conversions were $40 \%$ and $100 \%$, respectively (Figure 4). Both $\mathrm{H}_{2}$ and $\mathrm{CO}$ selectivities were $75 \%$ giving a $\mathrm{H}_{2} / \mathrm{CO}$ ratio of 2.0 . The general feature of $\mathrm{CH}_{4}$ conversion was similar to that with $\mathrm{CH}_{4} / \mathrm{O}_{2}=3.8$, in the point of giving oscillatory catalytic behavior. However, the period was shorter than that with $\mathrm{CH}_{4} / \mathrm{O}_{2}=3.8$, and the increasing rate of $\mathrm{CH}_{4}$ conversion after $1 \mathrm{~h}$ was high. Besides, the period giving high $\mathrm{CH}_{4}$ conversion was longer than $10 \mathrm{~h}$. These results indicate that the reduction of ceria could be accelerated and maintained for a long time when the degree of oxygen deficiency was heavier. Another interesting point is that $\mathrm{O}_{2}$ conversion was $100 \%$ when $\mathrm{CH}_{4}$ conversion was maintained to about $40 \%$. Thus, it could be suggested that the vacancies of $\mathrm{CeO}_{2}$ should be effectively supplied with gas-phase $\mathrm{O}_{2}$ molecules followed by the release of active oxygen species reacting with $\mathrm{CH}_{4}$ to produce synthesis gas when the degree of $\mathrm{O}_{2}$ deficiency was heavier. In addition, the $\mathrm{H}_{2} / \mathrm{CO}$ ratio was maintained to 2.0

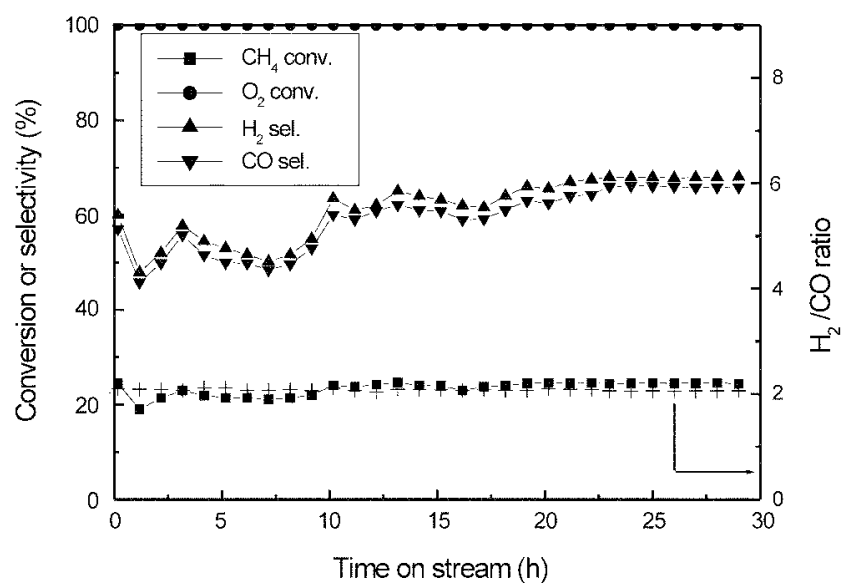

Figure 5. $\mathrm{CH}_{+}$oxidation over $\mathrm{CeO}_{2}$ with a $\mathrm{CH}_{4} / \mathrm{O}_{2}$ ratio of 6.0 $\left(\mathrm{CH}_{\downarrow}=30 \mathrm{~mL} / \mathrm{mun}, 50 \mathrm{mg}\right.$ catalyst, $\left.\mathrm{T}=1023 \mathrm{~K}, \mathrm{P}=\mathrm{l} \mathrm{atm}\right)$.

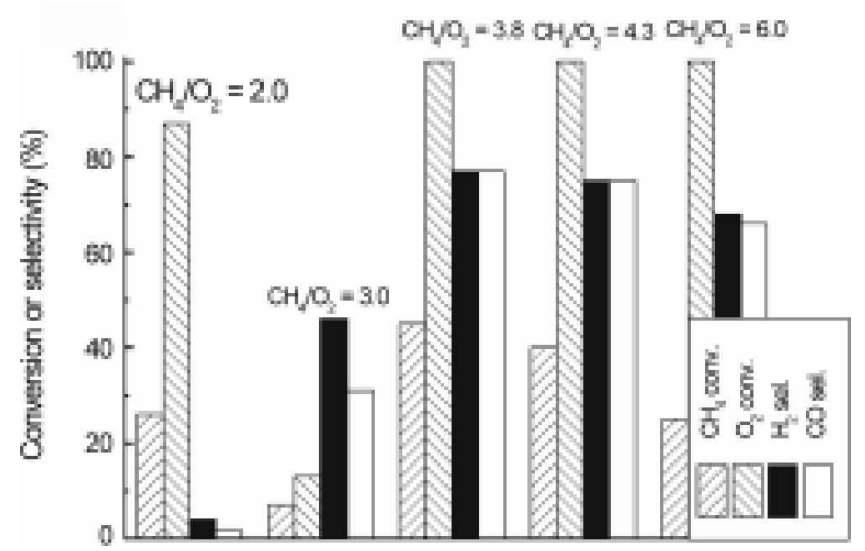

Figure 6. The eilect of $\mathrm{CH}_{4} / \mathrm{O}_{2}$ ratio on $\mathrm{CH}_{4}$ oxidation over $\mathrm{CeO}_{2}$ $\left(\mathrm{CH}_{4}=30 \mathrm{~mL} / \mathrm{min}, 50 \mathrm{mg}\right.$ catalyst, $\mathrm{T}=1023 \mathrm{~K}, \mathrm{P}=\mathrm{l}$ atm; Data at maximum $\mathrm{CH}_{4}$ conversion).

when $\mathrm{O}_{2}$ conversion was $100 \%$, indicating that $\mathrm{POM}$ was dominant at the condition. Figure 5 describes the results at a $\mathrm{CH}_{4} / \mathrm{O}_{2}$ ratio of 6.0 . In this condition, $\mathrm{CeO}_{2}$ exhibited continuous $100 \% \mathrm{O}_{2}$ conversion, $25 \% \mathrm{CH}_{4}$ conversion, $68 \%$ $\mathrm{H}_{2}$ selectivity, and $66 \% \mathrm{CO}$ selectivity with a $\mathrm{H}_{2} \mathrm{CO}$ ratio of 2.1 at steady state. This strongly indicates that continuous partial oxidation reaction can be possible over $\mathrm{CeO}_{2}$ by controlling the $\mathrm{CH}_{4} / \mathrm{O}_{2}$ ratio, namely, the degree of oxygen deficiency. Figure 6 summarizes the effect of $\mathrm{CH}_{4} / \mathrm{O}_{2}$ ratio on $\mathrm{CH}_{4}$ oxidation over $\mathrm{CeO}_{2}$ with various $\mathrm{CH}_{4} / \mathrm{O}_{2}$ ratios. The data shown in Figure 6 were taken from the maximum $\mathrm{CH}_{4}$ conversion during the reaction. As shown in Figure 6, it is clear that catalytic performance of $\mathrm{CeO}_{2}$ extremely depends on the feed ratio of $\mathrm{CH}_{4}$ and $\mathrm{O}_{2}$. It is noteworthy that $\mathrm{CeO}_{2}$ can be used as a catalyst for POM. Thus, it can be expected that the combination of $\mathrm{Ni}$ and $\mathrm{CeO}_{2}$ should give enhanced catalytic performance in the reaction related with $\mathrm{POM}$. This is possibly why $\mathrm{NiCeO}_{2}$ has been reported to give rather good activity in POM and exhibit high catalytic performance in OSRM. ${ }^{13.15}$

According to the above results, it was found that total oxidation of methane (TOM) is favorable at the stoichiometric feed ratio $\left(\mathrm{CH}_{4} / \mathrm{O}_{2}=2.0\right)$, POM is considerable at the condition of $\mathrm{CH}_{4} \mathrm{O}_{2}=3.0$, POM is dominant at the $\mathrm{CH}_{4} / \mathrm{O}_{2}$ ratio of 6.0 , and there is an oscillation of POM and TOM at the $\mathrm{CH}_{4} / \mathrm{O}_{2}$ ratio of between 3.8 and 4.3 . This is possibly related to the oxidation state of $\mathrm{Ce}$. It is due to the fact that the reduced ceria having oxygen vacancies $\left(\mathrm{Ce}^{3+}\right)$ could perform POM at oxygen deficiency condition. However, it is speculated that the state of oxygen vacancies are not so stable that $\mathrm{Ce}^{3+}$ quickly changes into $\mathrm{Ce}^{+-}$having negligible activity in POM. The change between $\mathrm{Ce}^{3-}$ and $\mathrm{Ce}^{++}$is reversible but the rate from $3+$ to $4+$ is faster than that from $4+$ to $3+$. This is possibly why $\mathrm{CH}_{4}$ conversion decreased sharply at the initial stage and gradually increased to some extent when the oscillation was observed.

Pulse reaction. In order to investigate the reaction mechanism, pulse experiments using $\mathrm{CH}_{4}, \mathrm{O}_{2}$ and $\mathrm{CH}_{4} / \mathrm{O}_{2}$ mixed gas $\left(\mathrm{CH}_{4} / \mathrm{O}_{2}=2.0\right)$ were performed in a micro-reactor at 
Table 1. Pulse reaction results over $\mathrm{CeO}_{2}$

\begin{tabular}{lccccc}
\hline Pulse type & $\mathrm{X}_{\mathrm{CH}+}(\%)$ & $\mathrm{X}_{\mathrm{O} 2}(\%)$ & $\mathrm{S}_{\mathrm{H} 2}(\%)$ & $\mathrm{S}_{\mathrm{CO} \%} \%$ & $\mathrm{H}_{2} / \mathrm{CO}$ ratio \\
\hline $\mathrm{CH}_{4}{ }^{a}$ & 0 & - & 0 & 0 & - \\
$\mathrm{O}_{2}{ }^{b}$ & - & 0 & 0 & 0 & - \\
$\mathrm{CH}_{4}{ }^{c}$ & 0 & - & 0 & 0 & - \\
$\mathrm{CH}_{4} / \mathrm{O}_{2}{ }^{a}$ & 26 & 87 & 4 & 1.5 & 5.0 \\
$\mathrm{CH}_{4}{ }^{2}$ & 0 & - & 0 & 0 & -
\end{tabular}

$\mathrm{CH}_{4}$ pulse was injected after the reduction of the fresh catalyst. "O pulse was injected after $5 \mathrm{CH}_{4}$ pulses. ${ }^{\circ} \mathrm{CH}_{4}$ pulse was re-injected after 5 $\mathrm{O}_{2}$ pulses. ${ }^{1} \mathrm{CH}_{4} / \mathrm{O}_{2}(2 / 1)$ pulse was injected after the reduction of the fresh catalyst. " $\mathrm{CH}$ pulse was injected after $5 \mathrm{CH}_{2} \mathrm{O}_{2}$ pulses.

$1023 \mathrm{~K}$. The pulse reaction results are summarized in Table 1. According to the pulse reaction results, $\mathrm{CeO}_{2}$ did not show any activity with only $\mathrm{CH}_{4}$ pulses. With $\mathrm{O}_{2}$ pulses after $5 \mathrm{CH}_{4}$ pulses, $\mathrm{CeO}_{2}$ did not show any $\mathrm{O}_{2}$ conversion, either. When $\mathrm{CH}_{4}$ pulse was re-introduced after $5 \mathrm{O}_{2}$ pulses, $\mathrm{CeO}_{2}$ did not show any activity, either. This indicates that lattice oxygen present in $\mathrm{CeO}_{2}$ does not react with $\mathrm{CH}_{4}$. Therefore, it was confirmed that $\mathrm{CeO}_{2}$ has no activity to decompose $\mathrm{CH}_{4}$ without regard to the oxidation state of $\mathrm{Ce}$. On the contrary, in the case of $\mathrm{CH}_{4} / \mathrm{O}_{2}$ pulses, $\mathrm{CeO}_{2}$ gave the same activities for total combustion as the continuous flow reaction results. When $\mathrm{CH}_{4}$ pulse was introduced after $\mathrm{CH}_{4} /$ $\mathrm{O}_{2}$ pulses, $\mathrm{CeO}_{2}$ did not show any activity. Therefore, it was confurmed that methane oxidations including both POM and TOM occur with coexistence of methane and oxygen over the $\mathrm{CeO}_{2}$ catalyst, indicating that lattice oxygen does not participate in the reaction over $\mathrm{CeO}_{2}$. Namely, active oxygen species reacting with $\mathrm{CH}_{4}$ should be supplied from the gasphase oxygen. Consequently, in order to perform POM, the active sites, $\mathrm{Ce}^{3+}$, should activate adsorbed oxygen immediately supplied from gas-phase oxygen to release activated oxygen species reacting with $\mathrm{CH}_{4}$. Generally, the Mars-van Krevelen mechanism is applicable in partial oxidation reactions catalyzed by oxide surfaces. ${ }^{21}$ This mechanism explained a stepwise donation of electrons which proceed through free-radical intermediates, e.g.,

$$
\begin{aligned}
& \mathrm{O}_{2}+\sqsupset+\mathrm{e}^{-} \rightarrow \mathrm{O}_{2}^{-} \\
& \mathrm{O}_{2}^{-}+\mathrm{e}^{-} \rightarrow \mathrm{O}_{2}^{2-} \\
& \mathrm{O}_{2}^{2-}+\sqsupset \rightarrow 2 \mathrm{O}^{-} \\
& \mathrm{O}^{-}+\mathrm{e}^{-} \rightarrow \mathrm{O}^{2-}
\end{aligned}
$$

where, $\neg$ indicates oxygen vacancies. It is obvious that oxygen vacancies, $\mathrm{Ce}^{3+}$, are active sites for POM and activated oxygen species should be one of the intermediates or the set of the intermediates. However, further spectroscopic study is necessary to verify it.

\section{Conclusions}

The $\mathrm{CH}_{4}$ conversion and the selectivities to $\mathrm{H}_{2}$ and $\mathrm{CO}$ over $\mathrm{CeO}_{2}$ are strongly dependent on the $\mathrm{CH}_{4} / \mathrm{O}_{2}$ ratio as follows. (1) $\mathrm{CeO}_{2}$ catalyzes total oxidation with a $\mathrm{CH}_{4} / \mathrm{O}_{2}$ ratio less than 2.0. (2) Continuous partial oxidation reaction is achieved over $\mathrm{CeO}_{2}$ only under significant oxygen deficient condition $\left(\mathrm{CH}_{4} / \mathrm{O}_{2} \geq 6.0\right)$. (3) $\mathrm{CeO}_{2}$ exhibits oscillatory catalytic behavior, and the period depends upon the feed composition under intemediate oxygen deficient condition $\left(4.3 \geq \mathrm{CH}_{4} / \mathrm{O}_{2} \geq 3.8\right)$.

In $\mathrm{POM}$ over $\mathrm{CeO}_{2}$, lattice oxygen does not participate in the reaction. The most probable reaction mechanism is that oxygen vacancies in reduced ceria are supplied with oxygen molecules from the reactant, and then activate adsorbed oxygen, followed by releasing activated oxygen species reacting with methane to produce $\mathrm{H}_{2}$ and $\mathrm{CO}$.

\section{References}

1. Tsang. S. C,; Claridge, J. B.; Green, M. L. H. Catal. Today 1995. 23,3,

2. Penia. M. A.; Gómez, J. P.; Fierro. J. L. G. Appl. Catal. A 1996. $144,7$.

3. Amor, J. N. Appl. Catal. A 1999, 176, 159.

4. Trovarelli, A.; de Leitenburg, C.; Botro, M.; Dolcetti, G. Catal. Today 2000. 50,353.

5. Lahaye. J.; Boehm, S.; Chambrion, P. H.; Ehrburger. P. Combustion and Flame 1996. 104. 199.

6. Matatow-Meytal, Y. 1.; Sheintuch, M. Ind. Eng. Chem. Res. 1998, 37,309 .

7. Liu, W.; Flytzani-Stephanopoulos, M. J. Catal. 1995, 153, 317.

8. Trovarelli, A. Catal. Rev-Sci. Eng. 1996, $38,439$.

9. Yao, H. C.; Yao. Y. F. Y. J. Catal, 1984, 86. 254.

10. Loong. C.-K.; Ozawa, M. J. Alloys Comp. 2000, 303-304. 60.

11. Otsuka. K.; Ushiyama. T.; Yamanaka. I. Chem. Lett. 1993, 1517.

12. Roh, H.-S; Dong, W.-S.; Jun, K.-W.: Park, S.-E. Chem. Lett. 2001, 88.

13. Dong, W.-S.: Roh, H.-S.; Jun, K.-W.; Park, S.-E.; Oh, Y.-S. Appl. Catal. A 2002, 226.63.

14. Roh, H.-S.; Jun. K.-W,; Dong, W.-S.; Park. S.-E.; Joe. Y.-I. J. Mol. Catal. $A$ 2002, 181. 137.

15. Roh, H.-S.; Jun, K.-W.; Dong, W.-S.; Park, S.-E.; Batek, Y.-S. Catal. Lett. 2001, 74, 31

16. Roh, H.-S.; Jun, K.-W.; Baek, S.-C.; Park, S.-E. Chem. Lett. 2001, 1048.

17. Dong, W.-S.; Roh. H.-S.; Lin. Z.-W.; Jun, K.-W.; Park, S.-E. Bt/l. Korew Chem. Soc 2001, 22. 1323.

18. Dong, W.-S.; Jun, K.-W.; Roh, H.-S.; Liu, Z.-W.; Park, S.-E. Catal Lett. 2002, 78, 215.

19. Diwell, A. F.: Rajaram, R. R.: Shaw, H. A.; Truex, T. J. Stud. Surf. Sci. Catal. 1991, 71, 139.

20. Tieman. M. J.; Finlayson, O. E. Appl. Catal. B 1998, 19. 23.

21. Gates. B. C.; Katzer, J. R.; Schuit, G. C. A. In Chemisny of Catalytic Processes; Ciofalo. R.; Marshall, D. J,; Leap, B.. Eds.; McGraw-Hill: New York, UI.S.A., 1979; p 346. 